\title{
Evidence for Early Human Arrival in Madagascar is Robust: A Response to Mitchell
}

\author{
James P. Hansford ${ }^{1,2^{*}}$, Patricia C. Wright ${ }^{3,4}$, Ventura R. Pérez ${ }^{5}$, Kathleen M. Muldoon ${ }^{6}$, Samuel T. \\ Turvey ${ }^{1}$, Laurie R. Godfrey ${ }^{5}$ \\ 1. Institute of Zoology, Zoological Society of London, Regent's Park, London NW1 4RY, UK \\ 2. Department of Biological Sciences, Northern Illinois University, DeKalb, IL 60115, USA \\ 3. Department of Anthropology, Stony Brook University, Stony Brook, NY 11794, USA \\ 4. Centre ValBio, Ranomafana, Ifanadiana 312, Madagascar \\ 5. Department of Anthropology, University of Massachusetts, 240 Hicks Way, Amherst, MA 01003, USA \\ 6. Department of Anatomy, College of Graduate Studies, Midwestern University, 19555 N. 59th Avenue, \\ Glendale, AZ 85308 \\ * Corresponding author
}

The colonization period of a given region can be defined by multiple types of evidence, including human bone records, environmental proxy signals in sediment cores, human-made artifacts, or anthropogenic modification of skeletal remains. The ability to interpret long-term impacts of human presence and past environmental interactions and define "natural baselines" of pristine ecosystems requires objective evaluation of all evidence. New techniques for studying human modification of bones have often provided evidence for much earlier regional human presence compared to evidence from sediment cores or physical artifacts (Holen et al. 2017; Dowd et al. 2016; Pitulko et al. 2016). However, when new lines of evidence challenge previously accepted paradigms of regional human arrival, they must, correctly, be subjected to intense scrutiny.

The narrative of human arrival on Madagascar is currently generating debate within the archaeological community due to recent publication of independent assessments of taphonomic evidence with differing conclusions. This has led to the widest range of estimates for earliest human presence on an island, from 10,500 BP to 1000 BP (Anderson et al. 2018; Hansford et al. 2018; Douglass et al. 2019). Early presence of humans on Madagascar is proposed on the basis of tool marks indicative of human butchery on an associated tibiotarsus and tarsometatarsus of an extinct elephant bird (Aepyornis maximus), which are directly dated to $>10,000$ BP (Hansford et al. 2018). These specimens originated from a palaeontological excavation at Christmas River (Ilakaka) in 2008 
led by Elwyn Simons, Patricia Wright, and Armand Rasoamiaramanana. Other specimens of extinct megafauna from this excavation are also dated directly to 10-11,000 cal. BP (Muldoon et al. 2012).

A review of tool marks on animal skeletal remains from new excavations in Madagascar was conducted by Anderson et al. (2018) and published two weeks after Hansford et al. (2018) without knowledge of the discovery from Christmas River. Anderson et al. (2018) reported no record of early human presence on Madagascar and challenged the reliability of earlier reported evidence of butchery dating from before the expansion of Indian Ocean trading networks. Soon afterwards, Mitchell (2019) published a similar critique, this time making specific reference to the data presented by Hansford et al. (2018). Both Anderson et al. (2018) and Mitchell (2019) described the need to distinguish cultural cut-marks from mechanical abrasion or biological damage; they begin with a null hypothesis of non-human agency, open to rejection on the basis of finding distinct toolmark morphologies and repetition. They also state that valid evidence must be produced through controlled excavations where absence of prior damage can be verified.

Mitchell (2019) proposed the following criteria: "1. the recovery of undeniable traces of ancient human activity in the form of artifacts (which may include cut-marked bone or otherwise modified natural materials); 2. the presence of such traces in undisturbed geological deposits in proper stratigraphic position, i.e. in primary context; 3. their unambiguous association with indisputable (generally radiometric) ages." Radiometric carbon (or other) dating must be conducted directly on key specimens rather than stratigraphically associated material, to avoid possible incorrect age inference due to specimen redeposition or misinterpretation of stratigraphic context.

Mitchell (2019) suggested that the evidence presented by Hansford et al. (2018) fails to meet these criteria and should therefore be rejected. In response to this, we here address the specific concerns of Mitchell (2019) and maintain the validity of our evidence for early human arrival in Madagascar. 
First, while conceding that marks on the Christmas River elephant bird bones are likely to be anthropogenic, Mitchell (2019) suggests they might represent damage by modern excavation tools. Parker Pearson et al. (2010) previously suggested that post-mortem damage cannot always be distinguished from peri-mortem tool marks. This suggestion, however, was not based on a peerreviewed empirical study evaluating the reproducibility of peri-mortem tool marks using excavation tools. The tool-marked specimens from Christmas River were scrutinized by independent teams of tool-mark experts in the UK and USA, who both approached their assessment of this evidence with extreme skepticism. The criteria used for cultural tool-mark assessment were identical to those of Anderson et al. (2018). We created detailed 3D profiles and observed distinct repeated kerf walls with crisp edges, which constitute undeniable evidence of human activity. Multiple features argue against these marks being produced by metal excavation tools, and support their production by lithic tools at or near the time of death. Cuts made by lithic tools are more variable in form than those from metal tools. Metal tools leave steep, smooth V-shaped kerfs on fresh bone, while lithic tools leave two different kerf walls: a smooth side that rises steeply and evenly, and a rough side that rises more gradually, and has multiple striae visible under high magnification that were produced by facets created during tool manufacture (Greenfield 1999). These features were all verified under high magnification using a VHX 5000 digital microscope at the University of Massachusetts Amherst's Violence and Conflict Laboratory (Hansford et al. 2018). Post-mortem damage produced by excavation tools can be further excluded using pattern (configurational) analysis: the location of the marks conforms to expectations for deliberate severing of limb segments at joints, suggesting purposefulness, which would not occur during excavation.

Second, Mitchell challenges the specimens' primary context, apparently on the basis of a comment article (Lawler 2018) not written by the authors. 
“... they lack a published stratigraphic section or other information detailing their exact origin within the locality's bone bed. An accompanying comment implies that they were among a group of "dinosaur bones" found by a local sapphire miner prior to 2008 and then stored by one of the paper's co-authors in a field research centre until examined by Hansford in 2016 (Lawler 2018); the sole additional reference notes that fossil bones were "collected", but does not furnish more than the most minimal further details (Muldoon et al. 2012:25)." (Mitchell 2019:10)

Thus, Mitchell (2019) states that the Christmas River excavation was uncontrolled and therefore should be discounted as evidence for early human arrival, irrespective of the veracity of radiometric dates for key specimens. We address this assertion directly because it is inaccurate.

The fossiliferous bed at Christmas River was discovered by sapphire miners in 2006 and reported to Patricia Wright in early 2007. In December 2007, Wright met with one of the miners, who presented her with hippopotamus and elephant bird femora and crocodile jaws (Simons et al. 2009). Wright was then invited to explore two sites (near llakakabe village, and at Christmas River). At Christmas River, she found a piece of wood, a jaw fragment of an extinct lemur (Megaladapis), and several hippo vertebrae in the spoils of the 2006 digging operation. After this initial site inspection, Wright invited palaeontologists Armand Rasoamiaramanana (Université d'Antananarivo) and Elwyn Simons (Duke University) to join her in mounting a major palaeontological expedition at Christmas River. Funding was secured from the National Geographic Society by Simons and the University of Helsinki by Jukka Jernvall, with a field expedition launched in August 2008. Because of the enormity of the task, local residents were hired to dig through meters of sediment under the scientists' direction and supervision. Beginning at the grassy modern site surface, the excavators dug through $15 \mathrm{~m}$ of lightbeige sandy soil, at the base of which megafaunal fossils began to appear. A sediment sample collected near the surface indicated the presence of plant and small vertebrate remains in sediments otherwise devoid of large fossils. Under the sandy soil was a fossiliferous gray-green layer of clay- 
rich soil at least $3 \mathrm{~m}$ deep (Figure 1). A 10×10 m area was roped and gridded into $1 \mathrm{~m}$ intervals. Megafaunal bones were removed from the clay, and Rasoamiaramanana and Wright sorted through the soil for smaller bones. Specimens were labelled and placed in bags (Simons et al. 2009). The team extracted over 600 megafaunal fossils from this layer, including large-bodied lemurs (Archaeolemur, Megaladapis, Pachylemur), elephant birds (Aepyornis maximus, Mullerornis modestus), the giant euplerid Cryptoprocta spelea, the endemic hippo Hippopotamus lemerlei, crocodiles, and tortoises (Muldoon et al. 2012). These fossils included an elephant bird tibiotarsus and tarsometatarsus that were found associated in situ, and were photographed in anatomical alignment (with a non-associated femur) shortly after excavation (Figure 2). Digging ceased after the bottom of the gray-green clay layer was exposed as the excavation had reached water.

Site excavation records include Simons' field catalogue, available at the Duke Division of Fossil Primates (Duke Lemur Center) and a scientific report to the National Geographic Society (Simons et al. 2009). Specimens are curated at Centre ValBio (Ranomafana), the Duke Division of Fossil Primates, and the National Museum of Natural History (Smithsonian). Simons' archived catalogue records only one excavated elephant bird tarsometatarsus (field number TA-08-51). As no tarsometatarsi were excavated by the miners, and the associated tibiotarsus and tarsometatarsus showing evidence of peri-mortem butchery are recorded from a systematic excavation, Criterion 2 of Mitchell (2019) is now clearly met.

Mitchell's third criterion was that dates be reliable. It is difficult to challenge radiometric dates for tool-marked specimens from Christmas River, as they were taken directly and measured at two radiocarbon facilities.

Shortly after excavation was completed, some mammalian fossils from Christmas River were brought to Duke University (Division of Fossil Primates), with two specimens (Archaeolemur sp. humerus, 
Pachylemur insignis femur) from the base of the sandy soil layer submitted for radiocarbon dating at the Lawrence Livermore National Laboratory in California. The great majority of specimens (616 individual bones) remained at Centre ValBio, and three of these specimens from the gray-green clay layer (one Hippopotamus lemerlei and two Aepyornis maximus bones, including the tibiotarsus later found to show tool-marks) were submitted for radiocarbon dating at the University of Helsinki. Muldoon et al. (2012) published a description of the fauna and its age based on these dates. The dates generated for these five specimens are consistent with their stratigraphic positions, with specimens from the sandy soil layer younger than those from the clay layer. Calibrated ages for all of the specimens exceeded 10,000 BP. Dating of several additional specimens failed because collagen preservation was too poor. In January 2016, after identifying clear evidence of peri-mortem damage consistent with human butchery on the two associated Aepyornis maximus bones, James Hansford selected the previously dated tibiotarsus for further dating. Its age was confirmed by a new date from a third radiocarbon dating facility (Belfast ${ }^{14} \mathrm{CHRONO}$ Centre; Hansford et al. 2018). Because of their importance, the associated Aepyornis maximus tibiotarsus and tarsometatarsus have been accessioned in the National Museum of Natural History (Smithsonian) on long-term loan (USNM A605208-A605209) and are available for further study.

We are therefore able to meet all three criteria proposed by Mitchell (2019) and defend our original interpretation of the antiquity of anthropogenic tool-marks on $\sim 10,500$-year-old elephant bird bones (Hansford et al. 2018). Indeed, as we provide multiple congruent AMS dates and clear evidence of peri-mortem human agency (tool marks), there is no logical reason to require an additional limiting criterion (evidence of stratigraphic context of key specimens) to accept evidence of early human presence on Madagascar.

We are also able to respond to the purported implausibility of the wider implications suggested by evidence for early human arrival. Mitchell questions "why evidence of human occupation before the 
mid-first millennium $A D$ is so scanty since surely successful colonization would, over millennia, have produced a much more plentiful material record than that currently known." Just $25 \%$ of Madagascar has been archaeologically explored, with rigorous surveys conducted in considerably less of this huge island's terrain. Most surveys have targeted surficial deposits dating to $800-1000 \mathrm{BP}$ (Davis et al. 2020). Satellite data suggest that recently-identified coastal archaeological contexts may yield information about early Holocene human settlement; this hypothesis must now be tested through excavations, to investigate whether limited archaeological evidence pre-dating $1000 \mathrm{BP}$ is the product of genuine absence or low search effort (Davis et al. 2020).

Mitchell (2019) also questions "if extinction did not closely follow human settlement, why did Madagascar differ in this respect from other island environments?" Again, this viewpoint is overly simplistic. Archaeological records from some islands (e.g., New Zealand) demonstrate that human arrival can drive rapid extinctions and faunal collapse, especially in large-bodied animals (Perry et al. 2014). However, our understanding of the timing and relationships between human arrival, faunal turnover, and ecosystem change in other islands is markedly less clear. Indeed, past human arrival on many islands was a demographically complex series of events, comprising multiple successive prehistoric colonizations associated with differing technologies and environmental impacts, with initial arrival not always associated with megafaunal loss. For example, Cuba, Hispaniola, and Puerto Rico experienced successive cultural waves of prehistoric human migration from the mid-Holocene onwards, but the Caribbean endemic insular megafauna (ground sloths and giant rodents, weighing up to $100 \mathrm{~kg}$ ) persisted for millennia after first human arrival (Cooke et al. 2017). Insular Southeast Asia provides another instructive example of spatiotemporally complex island extinction dynamics. Tigers disappeared during prehistory from some large Sunda Shelf islands (Hainan, Borneo, Palawan), but persisted until recently on Java and Bali and still survive on Sumatra; prehistoric human-megafaunal interactions thus varied substantially even between different populations of the same species (Diamond 1989; Piper et al. 2008). An inflexible paradigm of inevitable rapid 
megafaunal extinction following prehistoric human arrival therefore does not hold true for many islands. More nuanced, system-specific evaluation of evidence is required, taking into account varying conditions between different islands (e.g., existence of native mammalian predators) that might predispose different faunas to vary in vulnerability to prehistoric human interactions.

We argue that there is evidence for multiple migrations of humans to Madagascar that occurred during the Holocene. However, megafaunal extinction coincides with rapid human population expansion and major changes in subsistence strategies that occurred around 1000 BP (Godfrey et al. 2019). The identity, population size, and activities of these different waves of colonists raises fundamental research questions surrounding early human activity in Madagascar, and will be a source of intrigue for years to come.

\section{Acknowledgements}

We thank Matthew Borths for supplying the llakaka catalogue from Duke University's Division of Fossil Primates. The 2008 Christmas River expedition was funded by National Geographic Society, Stony Brook University, and University of Helsinki. This is Duke Lemur Center publication \#XXXXX. JPH, LRG, KMM, PCW, VRP and STT all contributed to the writing of this publication. Photographs are provided by PCW.

\section{References}

Anderson, A., G. Clark, S. Haberle, T.F.G. Higham, M. Nowak-Kemp, A. Prendergast, C. Radimilahy, L.M. Rakotozafy, J.L. Schwenninger, M. Virah-Sawmy, and A. Camens. 2018. New evidence of megafaunal bone damage indicates late colonization of Madagascar. PLoS One 13(10): e0204368.

Davis, D.S., V. Andriankaja, T.L. Carnat, Z.M. Chrisostome, C. Colombe, F. Fenomanana, L. Hubertine, R. Justome, F. Lahiniriko, H. Léonce, and G. Manahira. 2020. Satellite-based remote sensing rapidly reveals extensive record of Holocene coastal settlement on Madagascar. Journal of Archaeological Science 115: 105097.

Diamond, J.M. 1989. Quaternary megafaunal extinctions: variations on a theme by Paganini. Journal of Archaeological Science 16: 167-175. 
Douglass, K., S. Hixon, H.T. Wright, L.R. Godfrey, B.E. Crowley, B. Manjakahery, T. Rasolondrainy, Z. Crossland and C. Radimilahy. 2019. A critical review of radiocarbon dates clarifies the human settlement of Madagascar. Quaternary Science Reviews 221: 105878.

Dowd, M. and R.F. Carden. 2016. First evidence of a Late Upper Palaeolithic human presence in Ireland. Quaternary Science Reviews 139: 158-163.

Greenfield, H.J. 1999. The origins of metallurgy: distinguishing stone from metal cut-marks on bones from archaeological sites. Journal of Archaeological Science 26(7): 797-808.

Godfrey, L.R., N. Scroxton, B.E. Crowley, S.J. Burns, M.R. Sutherland, V.R. Pérez, P. Faina, D. McGee and L. Ranivoharimanana. 2019. A new interpretation of Madagascar's megafaunal decline: The "Subsistence Shift Hypothesis". Journal of Human Evolution 130: 126-140.

Hansford, J., P.C. Wright, A. Rasoamiaramanana, V.R. Pérez, L.R. Godfrey, D. Errickson, T. Thompson, and S.T. Turvey. 2018. Early Holocene human presence in Madagascar evidenced by exploitation of avian megafauna. Science Advances 4(9): eaat6925.

Holen, S.R., T.A. Deméré, D.C. Fisher, R. Fullagar, J.B. Paces, G.T. Jefferson, J.M. Beeton, R.A. Cerutti, A.N. Rountrey, L. Vescera, and K.A. Holen. 2017. A 130,000-year-old archaeological site in southern California, USA. Nature 544(7651): 479-483.

Mitchell, P. 2019. Settling Madagascar: When did people first colonize the world's largest island? The Journal of Island and Coastal Archaeology DOI: 10.1080/15564894.2019.1582567

Muldoon, K.M., B.E. Crowley, L.R. Godfrey, A. Rasoamiaramanana, A. Aronson, J., Jernvall, P.C. Wright, and E.L. Simons. 2012. Early Holocene fauna from a new subfossil site: A first assessment from Christmas River, south central Madagascar. Madagascar Conservation \& Development 7(1): 23-29.

Parker Pearson, M., K. Godden, Ramilisonina, Retsihisatse, J-L. Schwenninger, G. Heurtebize, C.M. Radimilahy, and H. Smith, (eds.). 2010. Pastoralists, Warriors and Colonists: The Archaeology of Southern Madagascar. Archaeopress, Oxford.

Perry, G.L., A.B. Wheeler, J.R. Woodand, and J.M. Wilmshurst. 2014. A high-precision chronology for the rapid extinction of New Zealand moa (Aves, Dinornithiformes). Quaternary Science Reviews 105: 126-135.

Piper, P.J., J. Ochoa, H. Lewis, V. Paz, and W.P. Ronquillo. 2008. The first evidence for the past presence of the tiger Panthera tigris on the island of Palawan, Philippines: Extinction in an island population. Palaeogeography, Palaeoclimatology, Palaeoecology 264(1-2): 123-127.

Pitulko, V.V., A.N. Tikhonov, E.Y. Pavlova, P.A. Nikolskiy, K.E. Kuper, and R.N. Polozov. 2016. Early human presence in the Arctic: Evidence from 45,000-year-old mammoth remains. Science 351(6270): 260-263.

Simons, E.L., P. Chatrath, J. Jernvall, S. Sova, P.C. Wright, A. Rasoamiaramanana, A. Rabotsy. 2009. Final Report to National Geographic Society: Christmas River Subfossil Site, Southcentral Madagascar. National Geographic Society. 